Ethos: Jurnal Penelitian dan Pengabdian kepada Masyarakat, Vol 9, No.1, Januari 2021: 15-22

\title{
Analisis Dampak Pembatasan Sosial dan KerJa di Rumah terhadaP PKL Kelurahan CeleP
}

\author{
${ }^{1}$ Deni Ainur Rokhim, ${ }^{2}$ Laila Nur Alfiah, ${ }^{3}$ Intan Ayu Idha Wulandari \\ ${ }^{1}$ Kimia, SMAN 3 Sidoarjo \\ 1,2,3,4Fakultas Matematika dan Ilmu Pengetahuan, Universitas Negeri Malang, Jawa Timur, Indonesia \\ email: 'deniainurrokhim@gmail.com, ${ }^{2}$ laylanuralfi@gmail.com, ${ }^{3}$ intan.ayu10@gmail.com
}

\begin{abstract}
The world is repairing the 2019 Corona Virus Disease pandemic (Covid19). The spread of Covid-19 is increasingly widespread, increasingly influencing the number of deaths and increasingly diverse aspects of life. The government provides policies regarding activities out of the house, school activities at home, work from home, even worship activities are at home. Street Vendors (PKL) in Celep Village, Sidoarjo. This study discusses community perspectives regarding government policy on Work From Home (WFH). Street Vendors (PKL) are able to fulfill their daily needs by selling along the road, so they have to take a trading holiday. Based on the results of research through the distribution of questionnaires to Street Vendors (PKL) in Celep $46.2 \%$, they strongly agree with the WFH policy, however, the policy concerns Street Vendors (PKL), which are needed to help meet the daily needs of Foot Traders Lima (street vendors).
\end{abstract}

Keywords: Corona Virus Disease, Work From Home (WFH), Street Vendors (PKL)

\begin{abstract}
Abstrak. Dunia sedang mengalami pandemi Corona Virus Disease 2019 (Covid-19). Persebaran Covid-19 semakin meluas, sehingga menyebabkan meningkatnya jumlah kematian dan mempengaruhi berbagai aspek kehidupan. Pemerintah memberikan kebijakan membatasi aktifitas keluar rumah, kegiatan sekolah di rumahkan, bekerja dari rumah (work from home), bahkan kegiatan beribadah pun di rumahkan. Kebijakan tersebut berdampak pada sektor ekonomi masyarakat khususnya para Pedagang Kaki Lima (PKL) di Kelurahan Celep, Sidoarjo. Penelitian ini bertujuan untuk mengetahui perspektif masyarakat berkenaan kebijakan pemerintah mengenai Work From Home (WFH). Pedagang Kaki Lima (PKL) mampu mencukupi kebutuhan sehari-hari dengan berjualan di sepanjang jalan, sehingga mereka harus libur berdagang. Berdasarkan hasil penelitian melalui penyebaran angket kepada Pedagang Kaki Lima (PKL) di Kelurahan Celep 46,2\% sangat setuju dengan kebijakan WFH tetapi kebijakan tersebut mempengaruhi penghasilan Pedagang Kaki Lima (PKL), sehingga dibutuhkan upaya pemerintah untuk mencukup kebutuhan sehari-hari Pedagang Kaki Lima (PKL).
\end{abstract}

Kata Kunci: Corona Virus Disease, Work From Home (WFH), Pedagang Kaki Lima (PKL)

\section{Pendahuluan}

Awal tahun 2020 ini, dunia sedang dilanda wabah virus corona (Covid-19) yang menginfeksi hampir seluruh negara di dunia. World Health Organization (WHO) semenjak Januari 2020 telah menyatakan bahwa dunia sedang mengalami darurat global terkait
Covid-19. Coronavirus adalah sekumpulan virus dari subfamili Orthocronavirinae dalam keluarga Coronaviridae dan ordo Nidovirales. Kelompok virus ini dapat menyebabkan penyakit pada burung dan mamalia, termasuk manusia. Coronavirus menyebabkan infeksi saluran pernapasan pada manusia yang umumnya ringan, 
seperti pilek, meskipun beberapa bentuk penyakit seperti; SARS, MERS, dan Covid-19 sifatnya lebih mematikan.

Terhitung mulai tanggal 19 Maret 2020 sebanyak 214.894 orang terinfeksi virus corona, 8.732 orang meninggal dunia dan pasien yang telah sembuh sebanyak 83.313 orang (Aida, 2020). Kondisi saat ini akibat virus corona tidak dapat diabaikan karena gejala yang ditimbulkam hanya sebatas bersin, batuk, dan demam, sehingga masyarakat akan menduga influenza saja. Hasil analisis kedokteran virus ini berbahaya dan mematikan. Perkembangan penularan virus ini cukup signifikan karena penyebaran dan penularan yang cepat seluruh negara merasakan dampaknya termasuk Indonesia. Antisipasi untuk mengurangi jumlah penderita virus corona di Indonesia telah dilakukan di berbagai daerah. Kebijakan membatasi aktifitas keluar rumah, kegiatan sekolah di rumahkan, bekerja dari rumah (work from home), bahkan kegiatan beribadah pun di rumahkan. (Zaharah \& Kirilova, 2020).

Kebijakan tersebut diharapkan mampu mengatasi masalah yang terjadi di masyarakat (Rohman, 2016). Penetapan kebijakan dilakukan dengan adanya penutupan beberapa akses jalan dalam waktu tertentu, pembatasan jumlah transportasi, pembatasan jam operasional transportasi yang berfungsi untuk menahan laju aktivitas masyarakat keluar rumah. Seluruh kegiatan di rumahkan yang disebut dengan istilah lockdown. Lockdown dapat membantu mencegah penyebaran virus corona ke suatu wilayah, sehingga masyarakat yang berada di suatu wilayah tersebut diharapkan dapat terhindar dari wabah. Kebijakan ini hanya dapat dilakukan oleh pemerintah dengan melakukan pemeriksaan secara ketat ke beberapa wilayah dan mempertimbangkan konsekuensinya dari segi ekonomi maupun sosial (Yunus \& Rezki, 2020).

Akibat kebijakan tersebut terdapat permasalahan yang muncul salah satunya bagi warga yang penghasilan sehari-hari berasal dari Pedagang Kaki Lima (PKL). Semenjak beberapa daerah memberlakukan pembatasan pergerakan orang, melakukan karantina parsial banyak Pedagang Kaki Lima (PKL) yang merugi karena pembeli sangat jarang bahkan sangat sepi. Beberapa pedagang masih mencari peruntungan berjualan meski dengan risiko, hal disebabkan karena kehidupan mereka sangat bergantung kepada pendapatan harian.

Di tengah merebaknya virus ini mereka harus tetap berjuang mencari nafkah agar mampu mencukupi kebutuhan sehari-hari. Pedagang Kaki Lima (PKL) mengaku akibat adanya wabah ini pendapatannya menurun sampai $50 \%$ dari sebelumnya. Sebelum wabah ini pendapatan mereka masih relatif cukup untuk memenuhi kebutuhan sehari-hari (Amaranti, 2018).

Dilansir oleh suaraindonesia sejumlah pedagang di Kabupaten Jember, Jawa Timur menjerit karena merugi (Anonim, 2020). Selain itu juga ditemukan beberapa kasus atau dampak di daerah Bandung bahwa warga atas nama Wahyu memilih untuk libur dari pekerjaannya karena pengeluaran dan pendapatan tidak seimbang (Jamil \& Firdaus, 2020).

$$
\text { Dampak Covid-19 juga }
$$
dirasakan para Pedagang Kaki Lima (PKL) yang beroperasi di sepanjang jalan besar di Kelurahan Celep, Sidoarjo. Kabupaten Sidoarjo yang kini masuk 3 wilayah PSBB di Jawa Timur memaksa para Pedagang Kaki Lima (PKL) untuk melakukan strategi dalam menghadapi Covid-19. Berdasarkan permasalahan yang di atas, maka perlu menganalisis dampak anjuran pembatasan oleh pemerintah bagi Pedagang Kaki Lima 
(PKL) di wilayah Kelurahan Celep, Sidoarjo.

\section{Metode}

Penelitian ini merupakan penelitian survey research menggunakan instrumen penelitian berupa angket secara online. Metode penelitian survei adalah metode penelitian kuantitatif yang digunakan untuk mendapatkan data yang terjadi pada masa lampau atau saat ini, tentang keyakinan, pendapat, karakteristik, perilaku, hubungan variabel dan untuk menguji beberapa hipotesis tentang variabel sosiologis dan psikologis dari sampel yang diambil dari populasi tertentu, teknik pengumpulan data dengan pengamatan (wawancara atau kuesioner) yang tidak mendalam, dan hasil penelitian akan di generalisasikan

(Sugiyono, 2017:8). Penelitian ini dilaksanakan di Kelurahan Celep Kota Sidoarjo Jawa Timur. Populasi dari penelitian ini adalah pedagang kaki lima yang berada di Kelurahan Celep berjumlah 13 responden. Pengambilan sampel dari populasi pedagang kaki lima di Kelurahan Celep dilakukan secara acak (simple random sampling).

Data yang diperoleh dari penelitian ini adalah data kualitatif dan kuantitatif Data kualitatif diperoleh dari perspektif pedagang dalam mengisi pertanyaan terbuka, sedangkan data kuantitatif diperoleh dari pendapat pedagang dalam menentukan kriteria jawaban. Teknik analisis yang digunakan penelitian ini adalah teknik analisis deskriptif. Teknik analisis deskriptif adalah teknik yang digunakan untuk menganalisis data dengan cara mendeskripsikan atau menggambarkan data yang telah terkumpul sebagaimana adanya tanpa bermaksud membuat kesimpulan yang berlaku untuk umum atau generalisasi (Sugiyono, 2017:147).

\section{Hasil dan Pembahasan}

Celep adalah sebuah Kelurahan di Kecamatan Sidoarjo, Kabupaten Sidoarjo, Jawat Timur. Berdasarkan Badan Pusat Statistika (2019) jumlah penduduk di Kabupaten Sidoarjo mencapai 2.249.476 jiwa. Kabupaten Sidoarjo yang dianggap sebagai kota terdekat dengan Kota Surabaya mengalami situasi yang tidak jauh berbeda dengan permasalahan pekerjaan (Aisyah, 2012). Pekerjaan yang paling banyak diminati masyarakat dan menjanjikan salah satunya adalah Pedagang Kaki Lima (PKL).

Pedagang Kaki Lima (PKL) yang berdagang hampir ada di sepanjang jalan di Kelurahan Celep Sidoarjo, sehingga kebanyakan masyarakat Kelurahan Celep mencari penghasilan bertumpu sebagai Pedagang Kaki Lima. Pandemi wabah Covid-19 membuat sektor perekonomian di berbagai daerah menurun, hal ini disebabkan karena adanya kebijakan dari pemerintah terhadap semua kegiatan yang dilakukan di luar rumah untuk dikerjakan di dalam rumah atau disebut Work From Home (WFH). Ketika Covid-19 belum mewabah di Indonesia sepanjang jalan Kelurahan Celep dipenuhi oleh orang yang sedang berinteraksi jual beli. Kondisi tersebut tidak dapat terjadi lagi ketika pemerintah menerapkan kebijakan Work From Home (WFH).

Kebijakan pemerintah mengenai Work From Home (WFH) memberikan dampak langsung kepada para PKL di Keluaran Celep Kabupaten Sidoarjo. Hal ini disebabkan karena para Pedagang Kaki Lima (PKL) mencukupi kebutuhan sehari-hari berasal dari penghasilan yang diperoleh ketika bekerja. Sepanjang jalan di Kelurahan Celep Sidoarjo terpantau sepi (Gambar 1), hanya beberapa Pedagang Kaki Lima (PKL) yang sedang berdagang. 


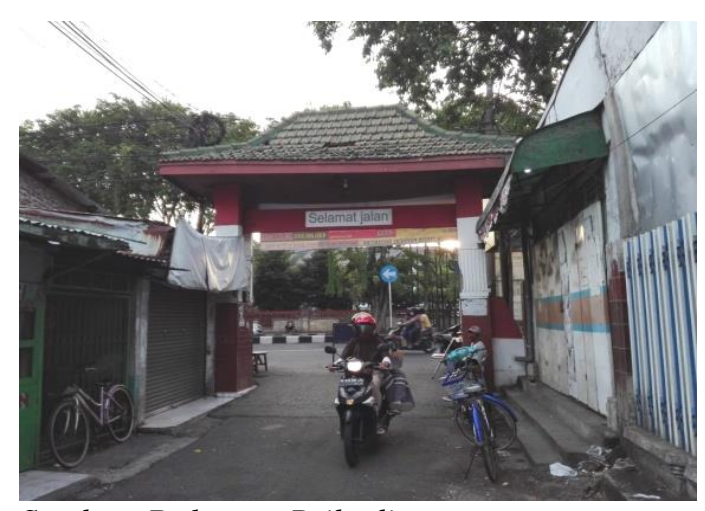

Sumber: Dokumen Pribadi

Gambar 1. Kondisi Ketika Kebijakan Work From Home (WFH)

Beberapa jenis Pedagang Kaki Lima (PKL) masih berjualan dan berdagang di sepanjang jalan Kelurahan Celep Sidoarjo (Gambar 2). Berdasarkan hasil observasi peneliti menyatakan bahwa Pedagang Kaki Lima (PKL) masih berdagang karena merasa tertekan akibat kebutuhan sehari-hari yang tidak terpenuhi.

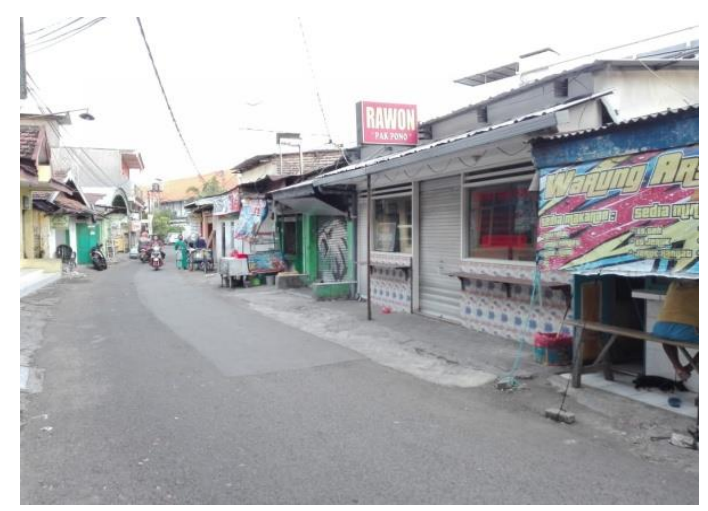

Sumber: Dokumen Pribadi

Gambar 2. Beberapa Pedagang Kaki Lima (PKL) Masih Berdagang

Beberapa jenis Pedagang Kaki Lima (PKL) di Kelurahan Celep yaitu pedagang makanan dan minuman, pedagang tekstil dan pakaian, dan pedagang sayuran, rempah, ikan, dan dagingBerdasarkan hasil angket pada Grafik 1 dengan menggunakan fasilitas google form pada Pedagang Kaki Lima
(PKL) melalui smartphone. Data yang diperoleh dari pernyataan pertama bahwa para Pedagang Kaki Lima (PKL) $46,2 \%$ setuju dan $7,7 \%$ sangat setuju dengan kebijakan pemerintah terkait pembatasan sosial dan kerja di rumah tetapi kebijakan tersebut mempengaruhi penghasilan Pedagang Kaki Lima (PKL). Hartono 43 Tahun bekerja sebagai pedagang makanan dan minuman yang telah bekerja selama 20 Tahun mengatakan bahwa penghasilan menurun. Hal tersebut juga terjadi pada Taklim 51 Tahun bekerja sebagai pedagang makanan dan minuman yang telah bekerja selama 10 Tahun mengatakan bahwa penghasilan menurun dan terpaksa tidak bekerja.

Dari paparan mereka juga didapatkan pernyataan mengenai alih perubahan berjualan menjadi berjualan online, akan tetapi mereka kesulitan karena tidak memiliki dasar berjualan online. Maka perlu dilakukan sosialisasi atau peralihan penjualan dalam basis online (Permana, 2019)

Grafik 1. Data Hasil Rekapitulasi Angket

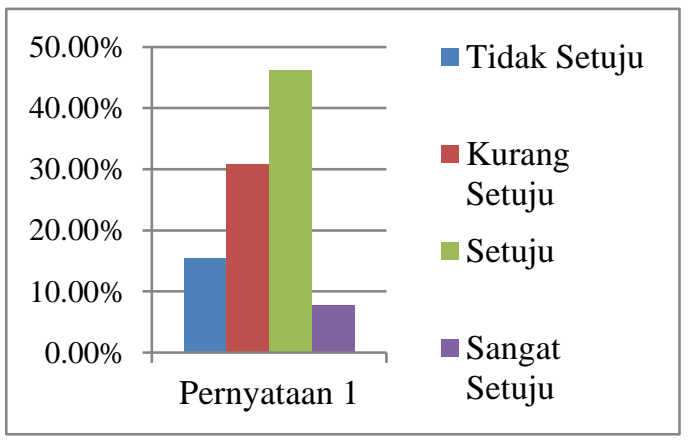

Kebijakan pemerintah juga berdampak pada pembayaran kredit, angsuran, dan hutang yang menyebabkan para Pedagang Kaki Lima (PKL) harus menunggak pembayaran. Presiden Joko Widodo, 29 Maret 2020 memberikan kebijakan untuk menangani dampak Covid-19 salah satunya memberikan keringanan kredit bagi masyarakat. Keringanan pembayaran kredit selama satu tahun bagi tukang 
ojek, sopir taksi, dan nelayan. Maka kebijakan tersebut tidak berpengaruh bagi para Pedagang Kaki Lima (PKL) yang sedang menanggung kredit. Hal ini menyebabkan delapan dari tiga belas responden yang mencapai 46,2\% memilih tetap berjualan dengan melaksanakan protokol kesehatan yang dianjurkan oleh pemerintah.

Berdasarkan data yang diperoleh dari pertanyaan kedua bahwa para Pedagang Kaki Lima (PKL) 46,2 \% setuju dan $46,2 \%$ sangat setuju yang dapat dilihat pada Grafik 2, berkenaan dengan penerapan standar operasional yang dianjurkan oleh pemerintah contohnya, menggunakan masker dan physical distancing antara penjual dan pembeli. Dimaun 51 Tahun bekerja sebagai pedagang makanan dan minuman yang telah bekerja selama 10 Tahun tetap menjual barang dagangannya dengan menggunakan masker dan menerapkan physical distancing. Hal tersebut juga terjadi pada Sumaji 55 Tahun bekerja sebagai pedagang sayur, rempah, ikan, dan daging yang telah bekerja selama 10 Tahun tetap menjual barang dagangannya dengan menggunakan masker dan menerapkan physical distancing. Pedagang Kaki Lima (PKL) yang tetap berjualan dengan menerapkan protokol kesehatan yang dianjurkan pemerintah memiliki rata-rata umur 50 tahun ke atas. Berdasarkan data yang diperoleh dari bbc.com menyatakan bahwa kaum lansia paling berisiko terpapar virus corona yang memiliki tingkat kematian mencapai 3,6\%. Hal ini akan memberikan risiko yang cukup besar jika mereka tetap berdagang di pinggir jalan.
Grafik 2. Data Hasil Rekapitulasi Angket

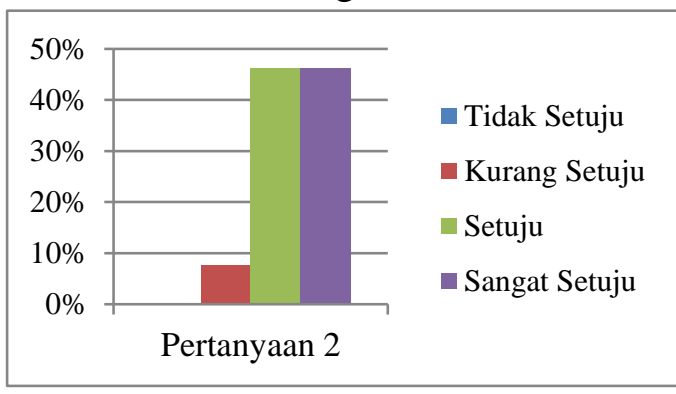

Berdasarkan peta sebaran covid 19 Jawa Timur Kabupatan Sidoarjo 80 orang positif Covid 19, 659 orang Orang Dalam Pemantauan (ODP), dan 159 orang Pasien Dalam Pemantauan (PDP). Peningkatan pasien Covid-19 menyebbakan Khofifah Indar Parawansa selaku Gubernur Jawa Timur mengajukan daerah Sidoarjo sebagai daerah yang akan menerapkan Pembatasan Sosial Berskala Besar (PSBB). Berdasarkan surat keputusan (SK) Kemenkes HK.0 1.071 MENKES I264I2O2O pada Selasa, 21 April 2020 menyetujui usulan penetapan PSBB di tiga wilayah Surabaya, Sidoarjo, dan Gresik (Detik.com). Menurut Wakil Bupati Sidoarjo Nur Akhmad Syaifudin menyatakan bahwa penerapan PSBB berencana akan dilaksanakan selama 14 hari dan bisa diperpanjang jika diperlukan (Kompas.com). Hal ini akan berdampak pada penghasilan pedagang kaki lima di Sidoarjo.

Berdasarkan poin penting PSBB di DKI Jakarta yang telah diberlakukan sejak Jumat, 10 April 2020 menyatakan bahwa fasilitas umum untuk memenuhi kebutuhan sehari-hari hanya pasar rakyat, toko swalayan, dan warung kelontong, sehingga anjuran pemerintah mengenai kerja di rumah dan PSBB sangat mempengaruhi penghasilan pedagang kaki lima. Penerapan PSBB di Kabupaten Sidoarjo akan dilaksanakan Selasa, 28 April 2020 sampai 11 Mei 
2020 diatur dalam Peraturan Bupati Sidoarjo Nomor 31 Tahun 2020 mampu mempengaruhi stabilitas ekonomi masyarakat Sidoarjo. Kelurahan Celep menjadi salah satu wilayah dalam penerapan PSBB, sehingga segala kegiatan masyarakat akan dibatasi dan diawasi (Gambar 3). Kondisi jalan utama Surabaya-Malang terlihat sedikit sepi, hal ini disebabkan karena penerapan PSBB dijaga ketat oleh pihak polisi untuk memantau para pengendara sepeda motor, mobil, atau lainnya untuk mematuhi peraturan yang telah berlaku.

Data yang diperoleh dari pertanyaan ketiga bahwa Pedagang Kaki Lima (PKL) 76,9\% sangat setuju, sehingga mengharapkan pemerintah memberikan kompensasi untuk memenuhi kebutuhan sehari-hari (Grafik 3).

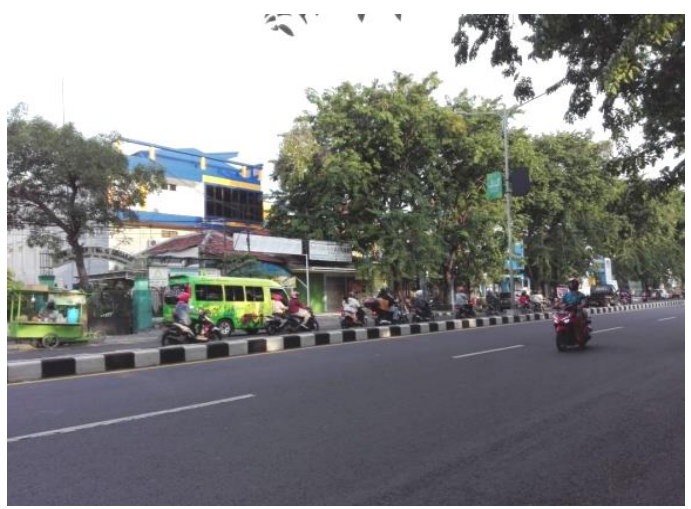

Sumber: Dokumen Pribadi

Gambar 3. Keadaan Ketika Kebijakan Pembatasan Sosial Bersakala Besar (PSBB)

Berdasarkan berita suarasurabaya.net terkait pemenuhan kebutuhan dasar penduduk, Pemerintah Provinsi dan Pemerintah Kabupaten/Kota dapat memberikan bantuan tunai dan/atau bantuan pangan non tunai kepada masyarakat terdampak selama PSBB. Bantuan diberikan dalam bentuk bahan pokok dan/atau bantuan langsung lainnya. Penerima bantuan ditetapkan sesuai ketentuan peraturan perundang-undangan.
Grafik 3. Data Hasil Rekapitulasi

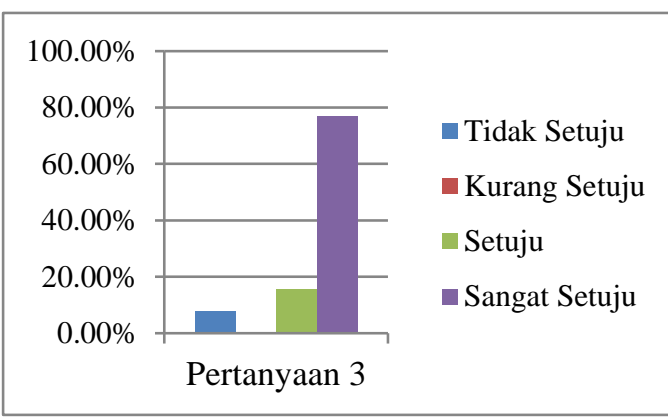

Angket

Berdasarkan hasil wawancara pada salah satu masyarakat Kelurahan Celep Selasa, 28 April 2020 belum mendapatkan penyaluran bantuan tunai/non tunai, sehingga menimbulkan keresahan masyarakat Sidoarjo untuk memenuhi kebutuhan sehari-hari.

\section{Kesimpulan dan Saran}

Pandemi wabah Covid-19 yang sedang menimpa berbagai daerah di Indonesia mengakibatkan pemerintah mengeluarkan kebijakan Work From Home (WFH). Kebijakan WFH memberikan dampak kepada beberapa masyarakat yang harus bekerja tidak di dalam rumah salah satunya Pedagang Kaki Lima (PKL). Pedagang Kaki Lima (PKL) mencukup kebutuhan sehari-hari dengan berdagang di sepanjang jalan di Kelurahan Celep, Sidoarjo. Akibat kebijakan WFH penghasilan Pedagang Kaki Lima (PKL) menjadi sangat menurun, sehingga mereka tidak mampu mencukupi kebutuhan sehari-hari dan membayar kredit. Pemerintah memberikan kebijakan mestinya sebagai salah satu jalan keluar untuk menekan angka penyebaran dan kematian akibat Covid-19, sehingga pemerintah juga harus berupaya agar semua pihak yang terlibat dapat diuntungkan. 


\section{Ucapan Terimakasih}

Saya mengucapkan terimakasih kepada para Pedagang Kaki Lima (PKL) di Kelurahan Celep, Sidoarjo Jawa Timur yang telah meluangkan waktunya untuk mengisi angket melalui google form.

\section{DAFTAR PUSTAKA}

Aida, N.R. (2020). Update Virus Corona di Dunia: 214.840 Orang Terinfeksi, $83.313 \quad$ Sembuh, $\quad 8.732$ Meninggal.Dunia. Kompas.Com .https://www.kompas.com/tren/read/ 2020/03/19/081633265/updatevirus-corona-di-dunia-214894orang-terinfeksi-83313-sembuh8732.

Aisyah, U. (2012). Pedagang Kaki Lima Membandel di Jawa Timur. Jurnal tidak diterbitkan Surabaya. Departemen Sosiologi FISIP Universitas Airlangga.

Amaranti, R., Nugraha, N., Nurrahman, A. A., \& Dzikron, M. (2018). PENINGKATAN KEMAMPUAN MANAJEMEN WIRAUSAHA UNTUK PEDAGANG KAKI LIMA DI LINGKUNGAN KAMPUS UNISBA. ETHOS: Jurnal Penelitian dan Pengabdian kepada Masyarakat, 6(1), 146-152.

Anonim. (2020). Dampak Virus Corona, Pedagang Kaki Lima Merugi _ Suara Indonesia. Dari https://www.suaraindonesia.co.id /galeri/read/2keqwcw9ue/dampak virus-corona-pedagang-kaki-lim amerugi\#!-_--

Badan Pusat Statistika. (2019). Statistik Kesejahteraan Rakyat Kabupaten Sidoarjo. Sidoarjo: Insert Coint Design.

British Broadcasting Corporation. (2020). Kajian Besar Terungkap Lansia dan Orang dengan Riwayat Penyakit Paling Berisiko Tertular Virus Corona. Indonesia: BBC Account. Dari https://www bbc.com/indonesia/dunia-515413 13.

Consumer News and Business Channel Indonesia. (2020). Pak Jokowi Membebaskan Kredit. Indonesia: A Transmedia Company. Dari https://www.Cnbcindonesia.com/ne ws/20200328100522-4-1481 28/saat-jokowi-bikin-hebohbebaskan-cicilan-kredit-faktanya.

Detik.com. (2020). Surabaya, Sidoarjo, dan Gresik Ajukan PSBB ke Kemenskes. Indonesia: Detik News. Dari https://news.detik. com/beritajawa-timur/d-4982914 /surabayasidoarjo-dan-gresik-akan-ajukanpsbb-ke-kemenkes.

Jamil, E. R. N., \& Firdaus. (2020). Corona Mewabah, Pedagang Kaki Lima Menjerit. Dari https://www.ayobandung.com/read $/ 2$ 020/04/02/84705/corona-mewa bah -pedagang-kaki-lima-menjerit.

Kompas.com. (2020). 2 Opsi Penerapan PSBB di Kabupaten Sidoarjo. Indonesia: PT Kompas Cyber Media. Dari https://regional.Kompas.com/read/2 020/04/21/2 $030 \quad$ 3811/2-opsipenerapan-psbb-di-kabupatensidoarjo.

Nurhalimah, N. (2020). Upaya Bela Negara Melalui Sosial Distancing Dan Lockdown Untuk Mengatasi Wabah Covid-19

(Efforts to Defend the Country Trough Social Distancing and Lockdown to Overcome the Covid-19 Plague ).

Peraturan Pemerintah Republik Indonesia Nomor 21 Tahun 2020. (2020). 2019, 1-5.

Permana, S. D. H., \& Cendana, M. (2019). Pemanfaatan Sosial Media sebagai Strategi Promosi bagi Sustainability Bisnis UMKM. ETHOS: Jurnal Penelitian dan Pengabdian kepada Masyarakat, 7(2), 163-169. 
Rohman, A. T. (2016). Implementasi Kebijakan Melalui Kualitas Pelayanan Penerimaan Pajak Daerah dan Implikasinya Terhadap Kepuasan Masyarakat di Dinas Pendapatan Kabupaten Kuningan (Issue 15) [Universiitas Pasundan]. Dari http://repository .unpas.ac.id/1661/.

Suara Surabaya.net. 2020. Hak dan Kewajiban Penduduk Surabaya, Sidoarjo, dan Gresik Selama PSBB. Surabaya: Suarasurabaya net. Dari https: //www.suarasura baya.net/kelanakota/2020/hak-dankewajiban-penduduk-surabayasidoarjo-dan-gresik-selamapsbb/?amp\&_twitter_impressi on=true Sidoarjo, dan Gresik Selama PSBB. Surabaya: tter_impressi on=true

Sugiyono. (2017). Metode Penelitian Kuantitatif, Kualitatif, dan R\&D. Bandung: Alfabeta.

Yunus, N. R., \& Rezki, A. (2020). Kebijakan Pemberlakuan Lock Down Sebagai Antisipasi Penyebaran Corona Virus Covid-19. SALAM: Jurnal Sosial Dan Budaya Syar-I, 7(3). https://doi.org/10.15408/sjsbs.v7i3.1 5083.

Zaharah, Z., \& Kirilova, G. I. (2020). Impact of Corona Virus Outbreak Towards Teaching and Learning Activities in Indonesia. SALAM: Jurnal Sosial Dan Budaya Syar-I, 7(3). https://doi.org/10.15408/ sjsb s.v7i3.15104. 